\title{
Model konserwacji zbiorów i jej wpływ na zakres informacji naukowej
}

$\int \begin{aligned} & \text { ednym z podstawowych problemów do rozwiązania dla zbiornic pi- } \\ & \text { śmiennictwa, powinno być zachowanie zgromadzonej informacji. Jest } \\ & \text { to problem złożony i trudny do rozwiązania.' }{ }^{\prime} \text { Ze względu na duże }\end{aligned}$
koszty, nawet w bogatych krajach, nie udało się do tej pory w sposób za-
dowalający rozwiązać tego problemu. Sytuacja wymusza stworzenie najefektywniejszego, realnego modelu. Z ekonomicznego punktu widzenia konserwacja nośników informacji jest bardzo droga. Na możliwość rozwiązania tego problemu wpłynie zmiana nastawienia. Dla życia biologicznego najważniejsze jest przekazanie informacji genetycznej, a nie zachowanie nośnika. Podobnie na wyższym poziomie szeroko rozumianej kultury, najważniejsze powinno być zachowanie i przckazanie użytecznej informacji (teoretycznej, technologicznej, praktycznej, historycznej, artystycznej itp.) dla podtrzymywania i rozwoju cywilizacji, a tylko w niektórych wypadkach zachowanie jej oryginalnego nośnika. Informacja naukowa (rozumiana jako zbiór wiedzy zapamiętanej np. w formie zapisu graficznego na papierze, elektronicznego na dysku optycznym itp.) jest operacyjną pamięcią zewnętrzną nauki (rozumianej jako wyższa forma zdolności adaptacyjnych człowieka) i powinna być traktowana jako specyficzny zapis wiedzy (kod naukowy) społeczeństwa ludzkiego (organizm społeczny). Większość bibliotek naukowych, jako zbiornice naukowo użytecznej, aktualnej informacji powinny stać się „twardymi dyskami” w „komputerze” nauki, a dodatkową rolę archiwum wiedzy pozostawić Bibliotece Narodowej. Prawidłowo zorganizowana biblioteka przyszłości stanie się ważną komórką sektora informacji.

Wchodzimy w erę społeczeństwa informatycznego. Właściwie dokonuje się rewolucja informatyczna. W cyfrowym świecie podstawowym surowcem jest informacja. O ekonomicznej potędze w świecie będzie decydowała ilość obywateli z wyższym wykształceniem i ilość pieniędzy przeznaczona na badania naukowe. Już obecnie w USA $60 \%$ PKB pochodzi z sektorów gospodarki zajmujących się informacja. ${ }^{2} \mathrm{~W}$ nowym systemie komunikacji społecznej możemy wyróżnić: 
a. przekaz tradycyjny za pomocą kodu graficznego zapisywanego najczęściej na papierze (podkreślić trzeba, że książki, czasopisma nie stały się formami zamierającymi, powstała nowa książka - atrakcyjna wizualnie, dobrze zilustrowana zdjęciami i grafika, z syntetycznym, encyklopedycznym tekstem.)

b. przekaz za pomocą nośników elektronicznych i optycznych (np. płyta CD, płyta DVD, taśma magnetyczna, taśma filmowa itp.)

c. bezpośredni przekaz elektroniczny (np. Internet, Intranet, E-mail, aktywna TV itp.)

Każde wejście na wyższy poziom cywilizacyjny łączy się z bardziej skomplikowanym oprzyrządowaniem. Kiedy powstał zapis graficzny na trwałym materiale uzależniliśmy się od konieczności produkowania niezbędnych przedmiotów, wynalazek druku stworzył cały przemysł, komputer potrzebuje elektryczności i urządzeń odczytujących. Energia elektryczna jest już oczywistością, a w niedalekiej przyszłości procesory będą czymś równie trywialnym jak mydło toaletowe. Dlatego irracjonalny strach przed nimi, jest tak samo niezrozumiały, jak strach starożytnego gawędziarza przed wynalazkiem tabliczki woskowej do zapisu pisma. Sprawa oprzyrządowania jest obecnie trudnym problemem, ale już teraz biblioteki powinny przygotować się do jego rozwiązania. Koszty sprzętu i pamięci będą coraz niższe, co pozwoli na jego upowszechnienie. Standard wyposażenia nie będzie odbiegał od poniższego zestawu:

a. wydajne skanery z oprogramowaniem konwertującym obraz tekstu w tekst (dobre programy typu OCR - optical character-recognition),

b. tanie i wydajne sposoby przechowywania informacji (podstawowy obszar pamięci i bezpieczne kopie zbiorów (min. 3),

c. łatwy system bieżącego odnawiania i ewentualnego konwertowania informacji cyfrowej na nowe nośniki (takie same lub nowsze technologicznie), bez utraty informacji (problem odnawiania nośników, ale jeśli np. będące w fazie eksperymentów płyty krzemowe ${ }^{3}$ będą miały trwałość np. 1000 lat, problemu nie będzie).

d. wydajne systemy wydobywania cyfrowej informacji, jej przesyłania i wydruku w dowolnej formie.

Materiały biblioteczne możemy podzielić na:

a. materiały dawne (podlegające konserwacji artystycznej i profilaktyce),

b. materiały współczesne (podlegające konserwacji masowej i profilaktyce),

c. materiały bieżące (podlegające konserwacji masowej i profilaktyce, a w przyszłości zabezpieczeniu informacji jako wartości). 
Zawartość materiałów bibliotecznych możemy podzielić na:

a. materiał ikonograficzny,

b. materiał informacyjny,

c. materiał metainformacyjny (informacja o materiałach bibliotecznych jako o obiektach materialnych).

Każdy materiał biblioteczny ma jakąś wartość, ale nie każdy wart jest zachowania. Istnieje pilna potrzeba wypracowania na polu naukowym obiektywnych metod oceny ich wartości, lub sposobów selekcji, ponieważ z powodów ekonomicznych nie będziemy w stanie zachować całości dorobku ludzkiego w tym zakresie (zarówno wartościowego jak i miernego). ${ }^{4}$ W ocenie wartości materiałów bibliotecznych musimy wziąć pod uwagę:

a. wartość artystyczną (niepowtarzalność, estetykę, reprezentatywność),

b. wartość informacyjną, naukową, literacką (aktualność informacji czyli stosunek zbiorów o wartości użytkowej do zbiorów o wartości archiwalnej - ocenę ułatwi skomputeryzowanic bibliotek; praktyczna użyteczność informacji zawartej w MB czyli ilość informacji rzeczywiście wpływającej na rozwój cywilizacyjny),

c. wartość historyczną (materiały biblioteczne jako źródła),

d. rzadkość występowania (ile egzemplarzy dzieła zachowało się do współczesności).

Konserwację materiałów bibliotecznych możemy podzielić na:

a. profilaktykę:

al: odpowiednie sposoby przechowywania i użytkowania,

a2: produkcja trwałych materiałów bibliotecznych.

b. konserwację artystyczna

c. konserwację masową:

c1: zabezpieczająca, i

c2: profilaktyczna.

d. zabezpieczenie informacji jako wartości.

\section{ad a Profilaktyka}

al Odpowiednie sposoby przechowywania i użytkowania.

Wiemy jak właściwie przechowywać materiały biblioteczne. Wiemy w jakich warunkach dany materiał jest najtrwalszy. Utrzymanie właściwej atmosfery jest kosztowne. Konieczne wydaje się upowszechnianie i wdrażanie, w przyszłych budowach, metod tanich w eksploatacji np. budowanie odpowiednich budynków $z$ grubych ceglanych murów, w których tworzy się specyficzny, korzystny dla zbiorów mikroklimat. W dalszej perspektywie czasowej wskazane byłoby wybudowanie dla archiwalnego dorob- 
ku narodowego głębokich, górskich magazynów. Warto zbadać dokładnie alternatywne, tanie sposoby utrzymania zbiorów w dobrej kondycji (ziołowe odstraszacze szkodników, ziołowe kappiele zabezpieczające, biopułapki, filtry grawitacyjne itp.).

a2 Produkcja trwałych materiałów bibliotecznych.

Znaczenie trwałości materiałów bibliotecznych jest coraz szerzej rozumiane nie tylko przez środowisko bibliotekarskie, ale także przez wydawców i producentów produktów papierowych. ${ }^{5}$ Podejmowane są wysiłki wielu środowisk na rzecz produkcji trwałego papieru. Opracowanie tańszej technologii produkcji zasadowego papieru niż technologia produkcji papieru w środowisku kwaśnym, stworzy lepsze przesłanki ekonomiczne na upowszechnienie się tych technologii. Dopiero wtedy nasz bieżący dorobek intelektualny, zapisywany na trwałym papierze, będzie miał szansę przetrwać w bibliotekach wiele lat.

\section{ad b Konserwacja artystyczna}

Jest to interdyscyplinarna dziedzina, której zadaniem jest zachowanie cennych, zabytkowych obiektów w dobrym stanie (spowalnianie procesów starzenia, uzupełnienie ubytków, rekonstrukcja i interdyscyplinarne badania naukowe). Praca nad konserwacją obiektów jest czasochłonna dlatego koszty jej są bardzo duże (koszt konserwacji książki oprawnej w skórę może przekroczyć 50.000,-). Z ekonomicznego punktu widzenia należy poddawać jej wyłącznie materiały dawne, o wysokiej wartości artystycznej i historycznej, znaczące dla kultury polskiej i światowej. Modele organizacji pracowni mogą być różne. W okresie przejściowym sprawdza się model zastosowany w Bibliotece Narodowej. Jednak w przyszłości konserwatorzy pracujący w czołowych bibliotekach (jako artyści rzemieślnicy) powinni być zrównani zawodowo z kustoszami. Stworzony specjalnie do celów pozyskiwania środków oddział reklamy i marketingu pozyskiwałby sponsorów i środki na artystyczną konserwację. Konserwacje wykonywane byłyby w ramach godzin służbowych, a po zakończeniu przedsięwzięcia, wysiłki gratyfikowane byłyby w postaci premii z funduszu np. na zasadzie $65 \%$ na premie, $35 \%$ na rzecz biblioteki (np. na masową konserwację profilaktyczna).

\section{ad c Konserwacja masowa}

cl Konserwacja masowa zabezpieczająca Masowe odkwaszanie i wzmacnianie - opracowano kilka metod masowego odkwaszania papieru i metodę wewnętrznego wzmacniania papieru. Przemysłowe linie do masowej konserwacji już są budowane. Dużą przeszkodą w upowszechnieniu urządzeń jest niekomercyjność technologii, dlatego wskazane jest łączenie wy- 
siłków na tym polu. Jeśli wysiłki powiodą się, wtedy jest szansa na masowe zabezpieczenie rozsypujących się materiałów bibliotecznych. c2 Konserwacja masowa profilaktyczna

To przysposobienie materiałów bibliotecznych do użytkowania, czyli nadanie trwałej użytkowej oprawy broszurom, książkom, czasopismom i gazetom. Niedocenianie tego zagadnienia powoduje poważne problemy ze zbiorami w dłuższym okresie czasu. Koszty tego sposobu zabezpieczania są znaczne (30-100 zł/sztukę). Sytuację poprawia produkcja coraz lepiej oprawionych książek. Jednak część materiałów bibliotecznych będzie zawsze wymagała przysposobienia (np. gazety) czy przeoprawienia, oraz jeśli zostaną uruchomione linie masowej konserwacji, odnowione materiałów bibliotecznych będą wymagały nowej, dobrej oprawy. W tym zakresie możliwe są różne modele rozwiązań: introligatornia własna i/lub współpraca $\mathrm{z}$ introligatornią prywatną.

\section{ad $\mathrm{d}$ Zabezpieczenie informacji jako wartości.}

Ważną dziedziną powinno stać się elektroniczne zabezpieczenie informacji. Będzie ono przebiegać dwunurtowo:

dl Zabezpieczenie informacji dawnej,.

d2 Zabezpieczenie informacji bieżącej.

Obecnie do zabezpieczania informacji stosuje się mikroformy (mikrofilm, mikrofisza). Wraz ze spadkiem kosztów digitalizacji zbiorów, w bibliotekach naukowych mikroformy zostaną zastapione kopiowaniem elektronicznym. Zadecyduje o tym coraz większa łatwość korzystania z elektronicznych zasobów informacji oraz praktyczna nietrwałość taśmy celuloidowej (np. mikrofilmy w BUW z lat 60-tych są już poważnie zniszczone). Mikroformy pozostaną sposobem jej archiwizowania do momentu, kiedy pamięci cyfrowe nie osiagną dużej trwałości (np. wypalane laserem płyty krzemowe - eksperymentalne prace prowadziło jedno z laboratoriów $\mathrm{NASA}^{6}$ ). W niedalekiej przyszłości zabezpieczenie informacji dawnej będzie odbywało się za pomocą przenoszenia na nośniki cyfrowe (digitalizacja) zawartości materiałów dawnych dużej i średniej wartości (konieczność rozwiązania problemu oceny wartości materiałów bibliotecznych) i współczesnych (także selekcja). Biblioteki podejmuja już wysiłki w celu sporządzania cyfrowych kopi książek. Zaletą cyfrowych zbiorów informacji jest możliwość przesyłania ich telełączami czy radiołączami. Drugą zaletą jest łatwość godzenia konieczności ochrony cennych obiektów z udostępnianiem ich osobom zainteresowanym (cenne obiekty skanuje się w kilku różnych rodzajach światła - np. jedyny średniowieczny manuskrypt poematu Beowulfz British Libra- 
ry został zeskanowany w świetle dziennym, podświetlony od tyłu i oświetlony ultrafioletem $)^{7}$. Następną zaletą jest możliwość otrzymania książki w kilka sekund i moźliwość korzystanie z niej przez wiele osób jednocześnie. Dużą zaletą jest to, że elektroniczna kopia zajmuje milimetry kwadratowe powierzchni dysków magnetycznych a nie metry sześcienne magazynów. W niedalekiej przyszłości dostępne staną się systemy umożliwiające łatwy i szybki wydruk dowolnie zestawionych skryptów (np. system KSEROX-a), a systemy druku bezpośredniego (druk offsetowy jest wykonywany bezpośrednio za pomocą komputera przygotowującego publikację bez pośrednictwa kliszy), umożliwi zmaterializowanie danej publikacji czy jej fragmentu w pojedynczym egzemplarzu, z wysoką jakością druku offsetowego (możliwość łatwego uzyskania reprodukcji faksymilowej). Koszty przekształcania materiałów bibliotecznych w formę elektroniczną są różne. Najtaniej jest skanować całe strony tworząc cyfrowe obrazy. W 1992 Annę Kenney z Cornell Uniwersity koszt zeskanowania jednego tomu XIX w. książki oceniła na 30-40\$ (przy czym głównym kosztem było wynagrodzenie obsługi skanera). Ale technika PhotoCD Kodaka automatyzująca proces skanowania koszty te znacznie obniża. ${ }^{8}$ Cyfrowy obrazy są wierne oryginałowi. Ale maja jeszcze poważną wadę. Można jej tylko oglądać. Nie ma prostych sposobów wyszukiwania cytatów, włączania ich do nowych dokumentów. Użycie programów OCR (skanowanie + użycie programu rozpoznawania znaków) pozwala elektroniczny tekst przekształcać, tworzyć skorowidze w edytorze tekstów itp. Na razie programy OCR doszły do $99 \%$ skuteczności, co oznacza, że na każdej stronie robią kilkanaście błędów. Mimo tego stosuje się już tę metodę. W programie archiwizacji wydawnictw Andrew W. Mellon Foundation zarchiwizowano w formie elektronicznej 10 popularnych periodyków ekonomicznych i historycznych za cenę $120 \$$ za 300 stronicową książkę (skanowanie, rozpoznanie znaków metodą OCR i korekta), a fundacja liczy na szybki zwrot kosztów dzięki zmniejszeniu kosztów katalogowania i magazynowania. ${ }^{9}$ Najwolniejszym a zarazem najdroższym sposobem wprowadzania książki do komputera jest ręczne jej wpisanie. W wypadku tekstów szczególnie formatowanych np. Oxford English Dictionary, jest to dobry sposób. Maszynistka wpisując tekst zachowuje osobliwości pisowni, literówki, krój czcionki itp. ${ }^{10}$ Zabezpieczenie informacji bieżącej jest o tyle prostsze, że coraz częściej informacja jest kodowana na nośnikach elektronicznych. Obecnie praca nad nową książka, pismem przebiega w komputerze. Wynik pracy jest zachowywany w formie elektronicznej i w większości przypadków archiwizowany w wydawnictwach na płytach 
optycznych. Bardzo niewiele trzeba, żeby na szczeblu ustawowym, zapisać egzemplarz obowiązkowy (obwarowany warunkami zabezpieczenia praw autorskich i wydawniczych) dla BN w formie cyfrowej i możliwość zakupu tej formy przez inne ważniejsze biblioteki. Konieczne wydaje się podjęcie wysiłków w celu zrealizowania tego prostego pomysłu. Bardziej skomplikowaną rzeczą są prawa autorskie i wydawnicze. Pod internetowym adresem Amazon.com można już zakupić elektroniczne wersje książek (istniejąca od 1995r. firma oferuje już ponad $3 \mathrm{mln}$ pozycji). Na prostej drukarce każdy sam może taką książkę wydrukować. Koszt druku z automatyczną oprawą wynosi około $1 \$$. Specjaliści z Doliny Krzemowej przewiduja, że już niedługo pojawią się na rynku popularne programy umożliwiające druk książek w domu czytelnika. Za pomocą telefonu i PC-ta przez Internet będzie można stworzyć sobie całą bibliotekę ${ }^{11}$. Problemami cyfrowych zbiorów informacji są prawa autorskie. Wydaje się konieczne jak najszybsze uregulowanie prawne tych spraw, bowiem rozwój cyfrowej informacji i korzystanie $\mathrm{z}$ niej może zostać utrudniony. Problemem też jest przejście $\mathrm{z}$ dawnej na nową formę korzystania $\mathrm{z}$ bibliotek. Stwierdzono, że jeśli $1 / 3$ zbiorów przyjmie formę wygodniejsza, to z pozostałej części czytelnicy przestają korzystać. ${ }^{12}$

Na zakończenie trzeba podkreślić, że najbardziej ambitne plany nie mają szansy realizacji, bez znalezienia źródeł ich finansowania. Niewątpliwie pierwszą fazą jest ustalenie analitycznego planu ratowania materiałów bibliotecznych przed zniszczeniem. Drugą fazą jest przeprowadzenie symulacji ekonomicznej, w oparciu o potencjalne możliwości finansowania, wielkości tych środków, w celu ustalenia najefektywniejszych sposobów ich wykorzystania. Symulacja umożliwi urealnienie planu ratowania materiałów bibliotecznych. Dopiero wtedy zasadne będą większe wysiłki w celu realizacji programu. Bez tego, wszelkie spotkania polegające na słownych deklaracjach, dobre chęci zebranych, tak jak i powyższy artykuł będzie można zaliczyć do pospolitego ,gdybajstwa”.

\section{LITERATURA}

1. Frace W., Whiffin J.I., Preserving our documentary heritage the case for permanent paper, IFLA (1996).

2. Porck H.J., Mass Deacidification, European Commission on Preservation and Access, Amsterdam 1996.

3. Ratowanie i ochrona zbiorów; Biblioteka Narodowa, Notes Konserwatorski nr 1, Warszawa1998. 
4. Robinson P. The digitization ofprimary textual sources, Ofice for Humanities Communication, University of Oxford 1993.

5. Building large-scale digital libraries, Computer, vol. 29, nr 5, V/1996 (wyd. specjalne).

6. Lesk M. Cyfrowe ksiażki, Świat Nauki, nr 5(69), V/1997, ss. 36-38.

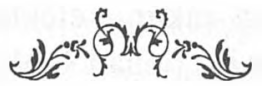

Przypisy:

'Fabian B., Ochrona zbiorów - wlasne refleksje, Notes Konserwatorski nr 1, Ratowanie i ochrona zbiorów, Warszawa 1998, ss.15-35.

${ }^{2}$ Bendyk E., Czlowiek w cyfrowym świecie, Wiedza i Życie nr 6/1998, s.4 (dodatku specjalnego).

${ }^{3}$ Informacja: TV Discovery Chanel pr. „Discover Magazin”, 16-IX-1998, h:21:50; $\mathrm{Na}$ dyskietkach wykonanych $\mathrm{z}$ twardych metali informacja zapisywana jest wiązka jonową. Dodatkowo wypalana jest zdefiniowana, odczytywalna pod mikroskopem instrukcja umożliwiająca odtworzenie danych.

${ }^{4}$ Manikowski A., Przedmowa, Notes..., op. cit., s. 12.

${ }_{5}^{5}$ Jarmińska D., Rams D., Ochrona dziedzictwa naszych dokumentów a trwały papier, Notes..., op. cit., s. 192.

${ }^{6}$ Patrz przypis 3.

${ }^{7}$ Lesk M., Cyfrowe ksiażki, Świat Nauki nr 5(69), maj 1997, ss. 36-38.

${ }^{8}$ Lesk M., Op.cit. s. 37.

${ }^{9}$ Ibidem.

${ }^{10}$ Ibidem.

1 J. Palarczyk, Wydruk na zamówienie, Rzeczpospolita nr 206(5066), 3 IX 1998r., s. 24

12 Lesk M., Op.cit. s. 38. 